\title{
Correction to: The Fate of Mud Nourishment in Response to Short-Term Wind Forcing
}

\author{
Kirstin Schulz $^{1} \cdot$ Knut Klingbeil $^{2} \cdot$ Claudia Morys $^{3} \cdot$ Theo Gerkema $^{4}$
}

Published online: 16 July 2021

(C) The Authors 2021

\section{Correction to: Estuaries and Coasts (2021) 44:88-102 https://doi.org/10.1007/s12237-020-00767-4}

The article The Fate of Mud Nourishment in Response to Short-Term Wind Forcing, written by Schulz et al., was originally published electronically on the publisher's internet portal on July, 30, 2020, without open access. With the authors' decision to opt for Open Choice the copyright of the article changed on May 20, 2021, to $\odot$ The Author(s) and the article is forthwith distributed under a Creative Commons Attribution 4.0 International License.

Open Access funding enabled and organized by Projekt DEAL. The original article has been updated.

The original article can be found online at https://doi.org/10.1007/ s12237-020-00767-4.

Kirstin Schulz

kirstin.schulz@awi.de

1 Alfred-Wegener-Institute Helmholtz-Zentrum für Polar undm, Meeresforschung, Bremerhaven, Germany

2 Department of Physical Oceanography and Instrumentation, Leibniz Institute for Baltic Sea Research Warnemunde, Seestraße 15, 18119 Warnemunde, IOW, Germany

3 Faculty of Science, Department of Ecology, Environment and Plant Sciences, Stockholm University, 10691 Stockholm, Sweden

4 Department, of Estuarine and Delta Systems, NIOZ Netherlands Institute for Sea Research, Utrecht University, P.O., Box 140, 4400 AC Yerseke, The Netherlands
Open Access This article is licensed under a Creative Commons Attribution 4.0 International License, which permits use, sharing, adaptation, distribution and reproduction in any medium or format, as long as you give appropriate credit to the original author(s) and the source, provide a link to the Creative Commons licence, and indicate if changes were made. The images or other third party material in this article are included in the article's Creative Commons licence, unless indicated otherwise in a credit line to the material. If material is not included in the article's Creative Commons licence and your intended use is not permitted by statutory regulation or exceeds the permitted use, you will need to obtain permission directly from the copyright holder. To view a copy of this licence, visit http://creativecommons.org/licenses/by/4.0/. 